\title{
Komunikasi Politik DPRD dalam Meningkatkan Peran Legislatif di Kota Bandung
}

\author{
Yadi Supriadi \\ Fakultas Ilmu Komunikasi, Universitas Islam Bandung, Jl. Tamansari No.1 Bandung 40116 \\ E-mail: supriadias71@gmail.com
}

\begin{abstract}
Abstrak. Dewan Perwakilan Rakyat Daerah (DPRD) merupakan lembaga legislatif yang sangat penting dalam sistem demokrasi sebagai jembatan antara masyarakat dengan eksekutif. Untuk menjalankan fungsinya, komunikasi politik menjadi strategi yang dilakukan untuk meningkatkan fungsi legislatif lembaga tersebut. Penelitian ini mengkaji tiga pokok persoalan dalam indentifikasi masalah, antara lain; (1) perencanaan komunikasi politik, (2) pesan komunikasi politik, dan (3) media komunikasi politik DPRD Kota Bandung dalam meningkatkan peran legislatif di Kota Bandung. Dengan menggunakan studi kasus, data penelitian dikumpulkan dari berbagai sumber yang variatif. Perencanaan komunikasi politik DPRD Kota Bandung dilakukan berdasarkan pesanpesan yang disaring dari berbagai sumber seperti kegiatan reses, informasi media massa, dan rutinitas rapat dewan. Pesan yang disampaikan dalam komunikasi politik dijalankan berdasarkan perencanaan yang telah dibuat, namun sebagian besar pesan dijalankan berdasarkan mekanisme kerja yang baku. Sementara itu media yang digunakan dalam melakukan komunikasi politik sangat beragam, mulai dari komunikasi langsung dengan masyarakat yang dikunjungi, sampai pemanfaatan media sosial seperti website, twitter, Instagram, dan faceboook. Sementara itu media yang digunakan dalam melakukan komunikasi politik sangat beragam, mulai dari komunikasi langsung dengan masyarakat yang dikunjungi, sampai pemanfaatan media sosial seperti website, twitter, Instagram, dan faceboook.
\end{abstract}

Kata kunci: perencanaan komunikasi, pesan, media, komunikasi politik

\begin{abstract}
Provincial Assembly (DPRD) is a very important legislative institution in the democratic system as a bridge between the community and the executive. in order to carry out its function, political communication becomes a strategy undertaken to improve the legislative function of the institution. This study examines three main issues in identifying problems, among others; (1) political communication planning, (2) message of political communication, and (3) political communication media of DPRD Bandung City in improving legislative role in Bandung City. Using case studies, research data were collected from a variety of varied sources. Planning political communication DPRD Bandung is based on messages filtered from various sources such as recess activities, mass media information, and board meeting routines. Messages delivered in political communications are run based on the planning that has been made, but most of the messages are run on the basis of a standard working mechanism. Meanwhile, the media used in doing political communication are very diverse, ranging from direct communication with the community visited, to the utilization of social media such as websites, twitter, Instagram, and faceboook.
\end{abstract}

Keywords: communication planning, message, media, political 


\section{PENDAHULUAN}

Dewan Perwakilan Rakyat Daerah (DPRD) adalah lembaga perwakilan tempatmasyarakatmenyampaikanaspirasi dan menyuarakan kepentingannya. Lewat lembaga ini akan keluar kebijakan yang menjadi dasar bagi eksekutif dalam menjalankan roda pemerintahan, baik yang diwujudkan dalam bentuk peraturan daerah, pengawasan, maupun anggaran.

Sinergi antara legislatif dan eksekutif tentu sangat diperlukan bagi kemajuan dan kesejahteraan masyarakat, namun tidak jarang keduanya saling bersitegang atau salah satu dari mereka lebih mendominasi komunikasi dalam tataran politik. Hal ini sebagaimana yang terjadi di Kota Bandung. Dinamika politik di Kota Bandung saat ini seolah didominasi oleh sosok Walikota Ridwan Kamil yang gencar dalam setiap perbincangan, pemberitaan, maupun di media sosial. Komunikasi Politik pemerintah seolah direduksi ke dalam bentuk komunuikasi langsung yang tertuju terhadap Walikota, padahal keberadaan DPRD sebagai bagian dari lembaga politik juga harus menjalankan peranananya dalam pelaksanaan komunikasi politik sehingga dapat menjadi jembatan politik bagi masyarkat.

Tugas dan fungsi DPRD Kota Bandung sebagai lembaga legislatif seolah redup tidak terlihat, lepas dari pemberitaan dan absen dari pengamatan dan perbincangan masyarakat. Padahal sebagai sebuah lembaga politik, legislatif memiliki fungsi yang sangat penting di hadapan masyakarat. Lembaga negara DPR/DPRD yang bertindak sebagai lembaga legislatif mempunyai fungsi, antara lain: (1) Fungsi legislasi, dalam arti penyusun dan pembuat undang-undang; (2) Fungsi anggaran, sebagai lembaga yang berhak untuk menetapkan anggaran belanja; (3) Fungsi pengawasan, sebagai lembaga yang melakukan pengawasan terhadap pemerintah yang menjalankan undang-undang.

Peningkatan peran dan fungsi legislatif DPRD Kota Bandung tentu sangat dibutuhkan guna mendorong partisipasi masyarakat dalam politik dan untuk meningkatkan citra posistif dari lembaga tersebut. Fakta memperlihatkan legistalif sering dihinggapi citra negatif dari masyarakat seperti praktek korupsi, tidak produktifdalammenghasilkan perda, atau sikap elitis yang jauh dari masyarkat. Tuntutan DPRD untuk menaikan tunjangan juga dipandang negatif meski dengan tujuan mencegah praktek korupsi. Koordinator Divisi Korupsi Politik Indonesian Corruption Watch (ICW) Donal Fariz menilai tunjangan dan gaji anggota Dewan Perwakilan Rakyat Daerah (DPRD) belum layak untuk dinaikkan. Ia mengatakan, berdasarkan Indeks Demokrasi Indonesia tahun 2015 yang dirilis oleh Badan Pusat Statistik (BPS) menunjukkan bahwa fungsi, peran, tata kelola kelembagaan dan kinerja DPRD rendah (Erdianto, 2016).

Partisipasi masyarakat dalam politik juga seringkali dimengerti dalam ruang yang terbatas, padahal DPRD memiliki peranan yang besar untuk meningkatkan partisipasi politik masyarakat dalam berbagai bentuk. Kondisi ini memperlihatkan bahwa politik bagi masyarakat bawah hanya sebatas pemilu atau pilkada. Interaksi dan komunikasi politik yang dilakukan masyarakat dengan anggota legislatif atau calon anggota legislaif sebatas kontrak politik. Selebihnya, masyarakat menginggalkan ruang yang lebih besar setelah legislatif terbentuk.

Komunikasi politik didefinisikan McNair (2003:4) sebagai purposeful communication about politics, yang mencakup: (a) Seluruh bentuk komunikasi yang dilakukan politisi dan aktor politik yang lain (selain politisi) dengan tujuan mencapai suatu tujuan tertentu; (b) komunikasi yang mengarah pada aktor- 
aktor di luar politisi seperti konstituen atau kolumnis surat kabar; serta (c) komunikasi tentang aktor dan aktivitasnya seperti yang terdapat pada laporan berita, editorial, dan diskusi lain mengenai politik di media. Aktivitas komunikasi politik ini terjadi dalam lingkup politik yang menurut Kaid (1999) melingkupi berbagai hal, seperti; berkenaan dengan realitas objektif sebuah politik dengen membandingkan kejadian-kejadian politik yang sedang berlangsung, realitas subjektif politik sebagaimana yang ditafsirkan oleh aktor dan masyarakat, dan konstruski sosial realitas politik yang dilakukan oleh media.

Sementara itu Moertopo (1974:19) menjelaskan tugas pokok legislatif(dalam hal ini DPR dan DPRD) melakukan proses legislasi dalam menentukan pokok-pokok kebijakan pemerintah dalam bentuk undang-undang, di bidang anggaran, legislatif menentukan anggaran belanja dan penerimaan negara atau daerah yang telah disepakati dengan pemerintah untuk melaksanakan kebijakan-kebijakan, dan dalam hal pengawasan legislatif berperan memonitoring pemerintah dengan berbagai alat atau hak yang mereka miliki.

Mengingat peran dan fungsi DPRD ini sangat penting, maka komunikasi politik DPRD sebagai lembaga terhadap masyarakat tidak dapat dikesampingkan, tujuannya tidak lain untuk meningkatkan pera legislatif itu sendiri. Tidak terkecuali dengan komunikasi politik DPRD dalam meningkatkan peran legislatif di Kota Bandung.

Penelitian ini mengkaji tiga pokok persoalan dalam indentifikasi masalah, antara lain: (1) perencanaan komunikasi politik; (2) pesan komunikasi politik; dan (3) media komunikasi politik DPRD Kota Bandung dalam meningkatkan peran legislatif di Kota Bandung.

\section{METODE}

Penelitian ini bermaksud untuk memaparkan komunikasi politik DPRD Kota Bandung dalam meningkatkan peran legislatif, mulai dari perencanaan, pengelolaan pesan komunikasi politik, hingga pemilihan media komunikasi politik yang digunakan. Dilakukan secara kualitatif dengan pendekatan studi kasus, tulisan ini bermaksud nyajikan pokok persoalan dari berbagai perspektif sumber.

Creswell (2002:61) menjelaskan bahwa secara umum pengertian studi kasus adalah penelitian yang menempatkan sesuatu atau objek yang diteliti sebagai sebuah kasus. Suatu objek dapat diangkat sebagai kasus apabila obyek tersebut dapat dipandang sebagai suatu sistem yang dibatasi yang terikat dengan waktu dan tempat kejadian objek. Mengacu pada kriteria tersebut, beberapa objek yang dapat diangkat sebagai kasus dalam penelitian studi kasus adalah kejadian atau peristiwa, situasi, proses, program, dan kegiatan. Sementara itu Yin (2003) mengemukakan bahwa studi kasus adalah sebuah metode penelitian yang secara khusus menyelidiki fenomena kontemporer yang terdapat dalam konteks kehidupan nyata, yang dilaksanakan ketika batasan-batasan antara fenomena dan konteksnya belum jelas, dengan menggunakan berbagai sumber data.

Yin juga menjelaskan mengenai persoalan ruang dan waktu dalam mendefiniskan kasus. Kasus yang baik dipandang kasus kontemporer, yakni peristiwa yang sedang berlangsung atau telah berlangsung tetapi masih menyisakan dampak dan pengaruh yang luas, terutama pada saat penelitian dilakukan. Subjek peneliti dijadikan sebagai instrumen dalam menentukan batasan yang disebut terikat ruang dan waktu itu. Jadi persitwa yang berdampak luas tidak selalu dikategorikan sebagai kasus, namun jika dampak itu berlangsung dan dampaknya masih terasa sampai subjek peneliti melakkan penelitian, 
maka itu menjadi kasus yang baik.

Informan dalam penelitian ini ditentukan dengan menggunakan purposive sampling, berdasarkan kriteria-kriteria tertentu yang telah dipertimbangkan dan sebagaimana menurut Kriyantono (2007:154) kriteria informan dipertimbangkan agar dapat mendukung tujuan penelitian. Tujuan dari penelitian ini tidak lain menjawab pertanyaan-pertanyaan penelitian yang sudah disampaikan pada bagian sebelumnya.

Analisis dalam tulisan ini dibangun melalui pertanyaan "bagaimana" dan "mengapa" yang dikumpulkan melalui pengumpulan data wawancara dan observasi. Dalam melakukan analisis terhadap perencanaan, pengelolaan, dan media komunikasi yang dipilih, tidak mengacu pada teori tertentu, namun lebih mengacu pada konsep-konsep komunuikasi politik dan efektivitas komunikasi.

\section{HASIL DAN PEMBAHASAN}

Kota Bandung merupakan kota metropolis yang belakangan akan dikembangkan menjadi kota teknopolis. Pembangunan infrastruktur terus dilakukan di Kota Bandung untuk menyelesaikan berbagai persoalan seperti tata ruang kota, kemacetan, ataupun yang berkaitan dengan keindahan kota. Geliat pembangunan di Kota Bandung sangat terlihat pada saat pemerintahan Ridwan Kamil yang hingga kini terus melakukan inovasi di kota kembang tersebut. Pembangunan yang dijalankan pemerintahan Kota Bandung bergerak cepat, pelayanan masyarakat dilakukan secara lebih efisen melalui pemanfaatan teknologi, ekonomi kreatif didorong menuju persaingan yang lebih besar, dan tentu pembangunan fisik seperti taman-taman kota menjadi penanda Kota Bandung sudah jauh berubah dari kondisi sebelumnya.
Perkembangan Kota Bandung ini juga didukung dengan kondisi sosial politik yang kondusif dimana saluran komunikasi politik masyarakat Bandung sangat terbuka, terutama komunikasi politik yang langsung tertuju pada pemerinta Kota Bandung. Sosok Ridwan Kamil yang memasyarakat, baik secara langsung maupun melalui media sosial telah menciptakan iklim komunikasi politik yang baik bagi masyarakat. Warga Kota Bandung bisa dengan mudah menyampaikan kritik dan saran terhadap berbagai hal yang berkaitan dengan Kota Bandung melalui akun pribadi walikota Bandung, baik facebook, twitter, maupun Instagram. Padahal, jika melihat dari sistem politik, masyarakat memiliki institusi yang bertugas sebagai penghubung antara masyarakat dengan pemerintah atau penyambung lidah masyarakat, yakni lembaga legislatif.

Aktivitas komunikasi politik yang dilakukan DPRD Kota Bandung pada dasarnya berlangsung dalam sebuah proses politik.

Proses politik ini ditandai dengan dua hal: (1) stabilitas politik, yang memungkinkan keberlangsungan pengharapan masyarakat dan penampilan pemerintah yang penting bagi proses politik itu sendiri; dan (2) demokrasi, yang memungkinkan partisipasi yang luas dan bermakna dari penduduk dalam menentukan kebijaksanaan umum (Rodee, 2000:214).

Keberadaan legislatif atau DPRD Kota Bandung tentu harus dimaksimalkan sehingga fungsi mereka bisa berjalan dengan baik demi kepentingan masyarakat. DPRD Kota Bandung periode 2014-2019 terdiri dari beberapa partai politik, dengan komposisi PDIP 12 kursi, Gerinda 7 Kursi, Demokrat 6 kursi, Golkar 6 kursi, Hanura 6 kursi, PKS 4 kursi, Nasdem 4 kursi, PPP 1 kursi, dan 
PKB 1 kursi. Total keseluruhan anggota DPRD Kota Bandung sebanyak 50 anggota.

Secara geopolitik, masyarakat Kota Bandung dipetakan ke dalam 6 wilayah atau lebih dikenal dengan sebutan dapil (daerah pemilihan). Dapil 1 terdiri dari kecamatan Andir, Cicendo, Sukajadi, Sukasari; dapil 2 terdiri dari kecamatan Bandung Wetan, Cibeunying Kaler, Cibeunying Kidul, Cidadap, Coblong, Sumur Bandung; dapil 3 terdiri dari kecamatan Batununggal, Kiaracondong, Lengkong; dapil 4 terdiri dari kecamatan Antapani, Arcamanik, Cibiru, Cinambo, Mandalajati, Panyileukan, Ujung Berung; dapil 5 terdiri dari kecamatan Bandung Kidul, Buahbatu, Gedebage, Rancasari, Regol, dan dapil 6 terdiri dari kecamatan Astana Anyar, Babakan Ciparay, Bandung Kulon, Bojongloa Kaler, Bojongloa Kidul. Berikut komposisi anggota legislatif/DPRD Kota Bandung periode 2014-2019.

TABEL 1. Anggota DPRD Kota Bandung Periode 2014-2019

\begin{tabular}{|c|c|c|c|}
\hline No & Nama & Partai & Daerah Pemilihan \\
\hline 1 & Rieke Suryaningsih & PDIP & \multirow{8}{*}{ DAPIL I } \\
\hline 2 & Aan Andi Purnama & Demokrat & \\
\hline 3 & Uung Tanuwidjaja & Nasdem & \\
\hline 4 & Deni Wahyudin & Gerindra & \\
\hline 5 & Willy Kuswandi & PDIP & \\
\hline 6 & Endrizal Nazar & PKS & \\
\hline 7 & Sofyanudin Syarif & Golkar & \\
\hline 8 & Agus Cahyana & Hanura & \\
\hline 9 & Riantono & PDIP & \multirow{9}{*}{ DAPIL II } \\
\hline 10 & Herman Budiono & PDIP & \\
\hline 11 & Salmiah Rambe & PKS & \\
\hline 12 & Nenden Sukaesih & Golkar & \\
\hline 13 & Hasan Faozi & Gerindra & \\
\hline 14 & Kurnia Solihat & Gerindra & \\
\hline 15 & Dudy Himawan & Nasdem & \\
\hline 16 & Ade Fahruroji & Hanura & \\
\hline 17 & Dede Hermawansyah & Demokrat & \\
\hline 18 & Achmad Nugraha & PDIP & \multirow{6}{*}{ DAPIL III } \\
\hline 19 & Erwan Setiawan & Demokrat & \\
\hline 20 & M. Al Haddad & Gerindra & \\
\hline 21 & Jhonny Hidayat & Golkar & \\
\hline 22 & Teddy Setiadi & PKS & \\
\hline 23 & J. Jhonson Panjaitan & Hanura & \\
\hline
\end{tabular}




\begin{tabular}{llll}
\hline 24 & Rendiana Awangga & Nasdem & \\
25 & Aries Supriatna & PDIP & \\
26 & Tatang Suratis & Golkar & DAPIL IV \\
27 & Haru Suandharu & PDIP & \\
28 & Sutaya & Gerindra & \\
29 & Edi Haryadi & PPP & \\
30 & Yusup Supardi & Hanura & \\
31 & Endun Hamdun & Demokrat & \\
32 & Entang Suryaman & PDIP & \\
\hline 33 & Kusmana & Golkar & \\
34 & Edwin Senjaya & Demokrat & \\
35 & Tomtom Dabbul Qomar & PKS & \\
36 & Tedy Rusmawan & Gerindra & \\
37 & Arif Hamid Rahman & PDIP & \\
38 & Iwan Darmawan & Nasdem & \\
39 & Asep Sudrajat & Hanura & \\
40 & Deden Deni Gumilar & & \\
\hline
\end{tabular}

(sumber: data peneliti)

\section{Perencanaan Komunikasi Politik}

Setiap anggota DPRD Kota

Bandung memiliki latar belakang pendidikan yang berbeda dan mereka juga datang dari partai politik yang berbedabeda. Dari perbedaan ini mendorong perlunya sebuah perencanaan komunikasi politik yang akan disampaikan kepada masyarakat tentang fungsi legislasi DPRP. Perencanaan ini pula yang akan menghindari kepentingan-kepentingan di luar tugas dan fungsi DPRD yang sesungguhnya.

Perencanaan komunikasi politik itu sendiri dilakukan guna menjamin berlangsungnya interaktivitas antara anggota legislatif dengan masyarakat Kota Bandung. Interaktivitas sendiri meliputi lima dimensi yaitu; arah proses komunikasi, fleksibilitas waktu dan peran dalam pertukaran, kesadaran akan lokasi dalam lingkungan komunikasi, level kontrol terhadap lingkungan komunikasi, dan tujuan proses komunikasi yang tercapai berorientasi pada pertukaran dan persuasi (McQuail dalam Adiputra, 2014: 224).

Dalam perencaan komunikasi politik, DPRD berangkat dari sistem yang baku yang telah menjadi kebiasaan di parlemen. Hal ini dilakukan agar anggota dewan dalam merencanakan komunikasi politik mereka tidak sembarangan dengan tetap mengikuti aturan yang berlaku dan melibatkan anggota masyarakat, agar harapan-harapan masyarakat bisa terpenuhi. Proses perencanaan ini terutama dilakukan pada saat DPRD akan merumuskan Peraturan Daerah (Perda) baru.

Untuk mengetahui problem dan pesan yang akan menjadi sasaran komunikasi politik, DPRD melakukan kunjungan kerja ke berbagai daerah. 
Kegiatan kunjungan kerja ini dianggap sangat efektif bagi anggota dewan untuk melakukan studi banding meski masih banyak pandangan negatif dari masyarakat mengenai kegiatan kunjungan kerja atau studi banding ini. Anggota DPRD mengungkapkan bahwa melalui kunjungan kerja ke daerah-daerah yang memiliki tingkat permasalahan yang setara dengan Kota Bandung mereka lebih bisa dalam melakukan perencanaan apa yang akan dilakukan dan dikomunikasikan kepada masyarakat Kota Bandung.

Perencanaan komunikasi politik yang dilakukan DPRD Kota Bandung masih terbilang sangat kaku. Hal ini terlihat dari input yang dilakukan dalam perencanaan masih mengacu pada kegiatan-kegiatan rutin yang mereka lakukan sebagai anggota dewan. Selain kunjungan kerja, bimbingan teknis atau biasa disebut bimtek juga menjadi acuan DPRD dalam melakukan perencanaan komunikasi politik. Bimbingan teknis yang dilakukan biasanya meliputi; optimalisasi fungsi dan wewenang DPRD dalam proses penyusunan dan penetapan APBD, optimalisasi peran DPRD dalam perencanaan dan evaluasi kinerja pembangunan daerah, optimalisasi reses dan pokok pikiran DPRD, bisa juga mengenai optimalisasi tugas dan tanggung jawab alat kelengkapan DPDR. Selain itu bimtek juga biasa dilakukan untuk kepentingan penguatan hard dan soft skills bagi anggota DPRD purnabakti, peningkatan kapasitas, peran dan fungsi anggota DPRD, semua bimbingan teknis ini dilakukan terngantung kebutuhan anggota DPRD tersebut.

Perencanaan komunikasi politik juga dilakukan dengan cara menganalisis dan memantau pemberitaan seputar DPRD Kota Bandung. Beberapa surat kabar dan media dijadikan acuan dengan cara melakukan monitoring terhadap pemberitaan mengenai DPRD Kota Bandung di media massa tersebut.
Hasil dari monitoring ini dapat menjadi acuan untuk membentuk perencanaan terutama dalam membangun opini publik positif mengenai legislatif. Jika mereka menemukan berita negatif atau tidak benar, maka perencanaan komunikasi yang dilakukan adalah seputar klarifikasi berita untuk memberikan respon kedepan, sementara jika berita seputar DPRD itu dianggap positif maka hal tersebut akan dijadikan patokan untuk meningkatkan kinerja mereka sebagai anggota dewan.

Sebagai komunikator dalam komunikasi politik, anggota legislatif Kota Bandung sangat dituntut untuk memiliki jangkauan luas tidak hanya sebatas daerah pemilihan mereka saja. Kegiatan komunikasi politik dalam hal ini juga dilakukan melalui pemetaan wilayah komunikasi di Kota Bandung sehingga semua komunikan; pemilih, konstituen, atau masyarakat bisa dijangkau secara lebih baik dalam kegiatan-kegiatan komunikasi yang rutin dilakukan anggota DPRD terutama dalam kegiatan reses. Perencanaan lain yang perlu dilakukan juga adalah proses pembentukan isu atau pesan komunikasi politik yang baik, yang menyangkut kepentinggan masyarakat Kota Bandung, hingga bagaimana proses pemilihan saluran media komunikasi politik yang mereka tentukan.

\section{Pesan komunikasi politik}

Dalam proses pengelolaan pesan komunikasi politik, para anggota dewan menyampaikan pesannya langsung kepada masyarakat yang diwakilkan oleh elemen-elemen masyarakat tertentu. Namun bila ada pesan atau peraturan yang tidak disetujui oleh beberapa masyarakat, akan ditinjau kembali. Ketidaksetujuan tersebut tidak diterima begitu saja, mereka memiliki badan khusus yang secara langsung mengolah pesan-pesan dalam DPRD. Jika anggota dewan menerima pesan yang tidak jelas, sudah tentu akan diabaikan, namun jika pesan tersebut 
memang memiliki muatan tertentu yang menyangkut nama baik anggota DPRD tersebut, maka badan khusus tersebut akan melakukan investigasi dan penyelidikan terhadap pihak yang bersangkutan dan melakukan klarifikasi terhadap pesan yang beredar dalam lingkup masyarakat.

Adapun pengelolaan pesan yang dilakukan DPRD Kota Bandung untuk menghindari pemberitaan-pemberitaan yang kurang baik maka harus adanya kepercayaan dari publik pada anggota dewan. Salah satu cara yang dilakukan adalah dengan melakukan Reses. Reses merupakan kegiatan yang dilakukan anggota dewan untuk turun langsung memantau daerahnya; apa yang sudah dan apa yang harus dikerjakan kedepannya. Dengan hal ini, dipercaya mampu memberikan kepecayaan publik terhadap DPRD dengan aksi nyata. Hak reses tiap anggota DPRD dapat dilakukan 3 kali dalam 1 tahun, artinya penyampaian pesan dilakukan secara akumulatif dalam kegiatan reses tersebut.

Istilah reses diadopsi dari kata recess (Belanda) yang berarti berlibur, istirahat atau turun main. Dalam makna asalnya, kata reses dikenakan pada liburan sekolah (semacam liburan semester setelah ujian) dan liburan parlemen (recess of parliament). Jadi prinsipnya berlibur untuk melepas kepenatan dan rutinitas di tengah masa tugas. Reses DPR/DPRD bermula dari kebiasaan orang-orang Belanda yang duduk sebagai anggota volksraad (DPR) dan regentschapsraad (DPRD setingkat kabupaten/kota) pada masa Hindia Belanda, yang mengadaptasi liburan musim panas di negara asal yang beriklim sub-tropis. Saat itu reses dilakukan sekali untuk waktu sekitar tiga bulan dalam setahun (Prihatmoko, 2006)

Pengelolaan pesan komunikasi politik para anggota dewan pun harus dapat dilakukan guna menaggulangi pesan negatif yang masuk ke DPRD. Cara mengelola pesan tersebut agar tidak terus menimbulkan polemik yaitu dilakukan dengan cara melakukan kerja nyata yang akan menghasilkan berita yang baik atau berita positif, sehingga pemberitaan negatif yang muncul terhadap DPRD secara tidak langsung diklarifikasi melalui pemberitaan akan hasil kerja para anggota dewan. Adapun jika anggota dewan atau bagian tertentu dalam DPRD memang terbukti bersalah atau terkait kasus hukum tertentu maka yang bersangkutan akan diserahkan kepada Badan Kehormatan Dewan yang akan memproses lebih lanjut tindakan yang akan diberikan kepada anggota DPRD tersebut.

Namun, tidak semua pesan dapat dikelola dengan baik oleh para anggota dewan. Ada hambatan-hambatan yang terjadi, salah satunya adalah keterbatasan anggota DPRD Kota Bandung yang tidak semua dapat langsung menerima aspirasi atau pesan dari masyarakat. Karena apa yang disampaikan dan harus dikerjakan tersebut membutuhkan proses panjang dan banyak aspek yang harus dikerjakan, sehingga diharapkan dalam hal ini masyarakat dapat membantu para anggota dewan dengan cara memberikan saran dan informasi mengenai kebijakankebijakan atau aspirasi yang seharusnya diperbaiki dan dibuat guna kepentingan bersama.

Dari pengamatan yang telah dilakukan, terutama melalui mediamedia di Kota Bandung, pesan-pesan yang disampaikan DPRD Kota Bandung kepada masyarakat sangat minim. Tidak ada isu politik yang signifikan dilakukan atau disampaikan DPRD Kota Bandung, begitu juga penyampaian pesan komunikasi politik hanya sampai di kelompok-kelompok tertentu yang memiliki akses terhadap lembaga legistatif tersebut. Fungsi legislatif seperti fungsi anggaran, fungsi pengawasan, dan fungsi legislasi seolah tidak dapat menjadi isu yang bisa disampaikan secara 
baik oleh anggota DPRD Kota Bandung dalam pengelolaan dan penyampaian pesan politik.

Meski penyampaian pesan komunikasi politik yang dilakukan DPRD Kota Bandung ini belum berjalan dengan maksimal, namun pesan-pesan inforamasi yang penting untuk masyakarat ketahui sudah mereka kelola melalui website resmi. Maksimalisasi penyampaian pesan yang dilakukan DPRD Kota Bandung ini meliputi informasi legislasi, jembatan aspirasi, serta pengelolaan media komunikasi politik.

Keberadaan DPRD Kota Bandung sangat penting dalam komunikasi politik. Dalam kacamata (Nasrullah, 2003:298) lembaga legislatif bisa dikategorikan sebagai input bagi sistem komunikasi politik. Menurut Nasrullah beberapa input yang harus ada dalam komunikasi politik diantaranya; (1) manusia yang hidup; (2) sarana komunikasi (isyarat, bahasa verbal, simbol, medium, dsb); (3) subjektivitas/kepentingan manusia (keinginan dan atau kebutuhannya); (4) organisasi sosial (RT, kelurahan, organisasi politik, organisasi massa, dsb); (5) situasi/keadaan-kehidupan-sosialekonomi-budaya-politik-keamananpertahanan-ideologi.

Pesan komunikasi politik DPRD kota Bandung berkaitan dengan fungsi legislatif memang sangat minim di pemberitaan media massa, hal ini sangat berbeda dengan aktivitas pesan di media sosial terutama Instagram. Melalu akun instagram, DPRD Kota Bandung memperlihatkan aktivitas legislasi mereka yang sangat beragam seperti rapat badan anggaran, rapat paripurna, penerimaan tamu kunjungan kerja, rapat kerjasama dengan dinas-dinas terkait persoalan yang sedang dikaji, peninjauan banjir, kegiatan talk show, aktivitas suling (subuh keliling), atau menghadiri acara musyawarah daerah. Pesan komunikasi politik berkaitan dengan fungsi legislatif ini dikemas melalui foto-foto kegiatan dewan dengan penjelasan teks yang ada di bawahnya. Melalui fasilitas instagram, DPRD Kota Bandung leluasa dalam menyampaikan pesan berkaitan dengan tugas dan tanggung jawab mereka.

\section{Media komunikasi politik}

Media komunikasi politik yang dilakukan DPRD Kota Bandung tentunya menggunakan media massa. Media massa dianggap dapat dengan mudah menyebarkan informasi langsung kepada seluruh masyarakat tanpa terbatas jarak. Para anggota DPRD Kota Bandung menilai, media yang paling efektif digunakan sampai saat ini adalah surat kabar. Mereka menilai surat kabar memiliki jangkauan yang luas dan mencakup berbagai macam golongan. Ada efek tertentu yang dirasakan ketika menyampaikan berita di surat kabar, salah satunya adalah pengetahuan masyarakat mengenai dewan atau mengenai Peraturan Daerah terbaru.

Namun tidak semua pesan langsung disampaikan begitu saja. Pesan tersebut harus dikaji bersama-sama terlebih dahulu sehingga berita yang disampaikan kepada masyarakat benar, faktual dan valid. Hingga saat ini, DPRD Kota Bandung sangat konsen terhadap pemberitaan yang menyangkut nama baik mereka. Opini masyarakat yang berkembang mengenai keberadaan DPRD yang dinilai masyarakat belum makasimal menjadi perhatian juga bagi DPRD Kota Bandung. Upaya melakukan respon inilah yang menjadi salah satu bagian dalam pengelolaan media komunikasi politik.

Selain memanfaatkan media massa yang sudah ada, DPRD Kota Bandung juga memaksimalkan inforamsi dan pesan komunikasi politik melalui buletin, website, dan akun soal facebook, twitter dan instagram. Dalam website yang dikelola DPRD Kota Bandung ini masyarakat dapat mengakses informasi- 
informasi yang dibutuhkan, seperti kedudukan, fungsi, hak dan kewajiban legislatif, alat kelengkapan dewan, program kerja, kebijakan, peraturan daerah, sertaberbagailaporan menyangkut lapora keuangan atau akuntabilitas kinerja pemerintah. Aktivitas ini dikenal dengan sebutan siberaktivisme. Siberaktivisme secara singkat dapat didefinisikan segala tindakan politik yang menggunakan media baru. Siberaktivisme lahir karena perkembangan media baru dan semakin terbukanya politik di Indonesia (Adiputra, 2014: 221).

Media website ini (dprp.bandung. or.id) tampak dimaksimalkan dengan memasukan berbagai informasi, tidak terkecuali berita-berita dari media lain menyangkut DPRD Kota Bandung. Mereka juga coba menjembatani komuniksi dengan masyarakat melalui laman saran atau aspirasi masyarakat.

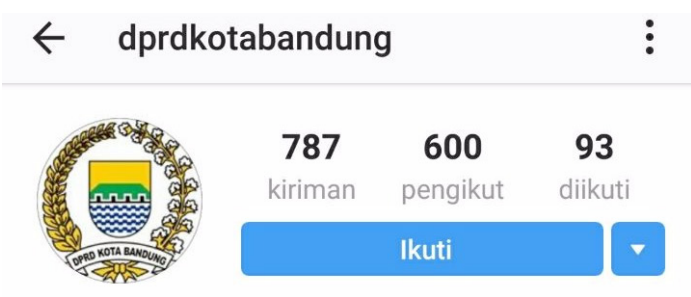

Akun IG Resmi \#DPRDKOTABANDUNG dprd-bandungkota.go.id/

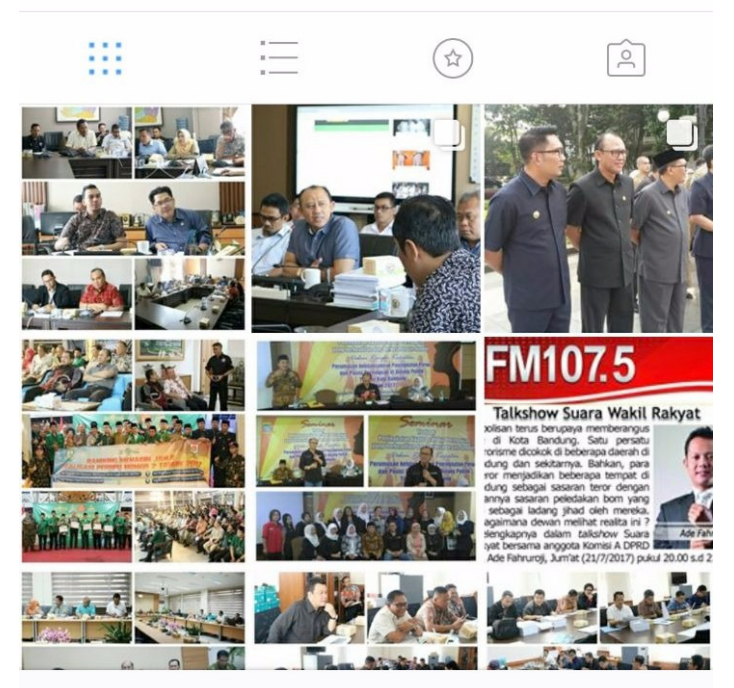

GAMBAR 1. Instagram Lembaga DPRD Kota Bandung (sumber: dok. peneliti)
Meski dibuat selengkap mungkin sebagai media komuniksi, aspirasi masyarakat bisa dibilang sangat minim. Kolom atau laman aspirasi masyarakat masih belum dimanfaatkan dengan sebaik-baiknya. Aspirasi terakhir yang peneliti temui tertanggal 6 April 2016, ini artinya satu tahun berselang tidak ada masyarkat yang menyampaikan aspirasi kepada DPRD Kota Bandung melalui laman website. Begitu juga feedback atas keluhankeluhan masyarakat pada laman aspirasi tersebut tidak ada. Tidak ada respon dari pengelola website DPRD Kota Bandung, dan ini menjadi asumsi kenapa laman aspirasi tidak dimaksimalkan dengan baik oleh masyarakat Kota Bandung.

Tidak mau ketinggalan dengan perkembangan zaman yang ditandai perkembangan media sosial, DPRD Kota Bandung juga memanfaatkan Instagram dan twiiter sebagai media komunikasi politik terhadap masyarakat Kota Bandung. Di akun resmi Instagram, DPRD Kota Bandung menampilkan berbagai foto kegiatan yang berkaitan dengan fungsi dewan, baik itu fungsi legislasi, fungsi anggaran dan fungsi pengawasan. Pengelolaan foto-foto kegiatan dewan di instagram dilakukan semenarik mungkin untuk membangun komunikasi antara DPRD Kota Bandung dengan masyarakat. Namun dari keseluruhan foto yang ditampilkan di Instagram tersebut, respon masyarakat sangat minim, hampir setiap foto yang ditampilkan tidak mendapatkan respon. Berikut contoh media sosial instagram yang dikelola DPRD Kota Bandung untuk menjangkau masyarakat Kota Bandung (gambar 1).

Secara keseluruhan, instagram DPRD Kota Bandung ini sudah dikelola dengan sangat baik, hal ini terbukti dengan infomasi atau foto yang ditampilkan selalu up date. Begitu juga penggunaan tagar (hastag) sudah dilakukan sesuai dengan foto atau gambar yang ditampilkan. Pengelolaan dan penyajian gambar di 
akun instaram DPRD Kota Bandung juga dilakukan secara konsisten. Meski demikian, DPRD Kota Bandung perlu menyadari bahwa pengguna instagram sangat tersegmen ke kalangan remaja atau anak muda, sehingga gambar atau foto yang ditampilkan di akun instragram DPRD Kota Bandung harus lebih menarik, variatif, namun tetap tidak meninggalkan fungsi inforamtif.

Jumlah follower instagram DPRD Kota Bandung mamang belum sebanding dengan jumlah penduduk dan pengguna instagram di kota Bandung. Namun demikian, upaya dalam pengelolaan media sosial yang dilakukan oleh DPRD Kota Bandung sudah membuahkan hasil dengan munculnya respon secara langsung di instagram DPRD Kota Bandung berupa "like". Sejauh ini, instagram tersebut belum mendapatkan respon berupa komentar-komentar.

Meski demikian, DPRD Kota Bandung telah berupaya untuk mengelola sosial media mereka dengan baik. Aktivitas yang mereka lakukan selalu mereka sampaikan melalui akun resmi media sosial mereka, begitu pula dengan akun resmi twitter yang mereka kelola.@DRPDKotaBandung sebagai akun resmi legislatif juga bersinergi dengan akun instagram dan website DPRD Kota Bandung. Informasi yang mereka sampaikan terintegrasi dengan berbagai media sosial baik mengenai penampungan aspirasi masyarakat, penerimaan kunjungan keja dari DRPR kota lain, audiensi dengan masyarakat, atau kegiatan-kegiatan seremonial lainnya. Hal yang sama juga terjadi dengan pengikut akun resmi DPRD Kota Bandung yang bisa dikategorikan minim untuk ukuran akun instansi publik. Berikut tampilan akun twitter DPRD Kota Bandung dengan nama@ DRPDKotaBandung (gambar 2).

Pada akun twitter DPRD Kota Bandung tercatat mulai aktif dari tahun 2011, artinya legislatif periode 20142019 mendapat limpahan dari pengelola sebelumnya. Jika dilihat, posting twit tampaknya jadi materi yang sulit untuk dikelola dibanding posting gambar dan video. Hal ini dimaklumi karena membuat deskripsi teks atau tulisan yang menarik dan membuat tagar yang bisa menjadi

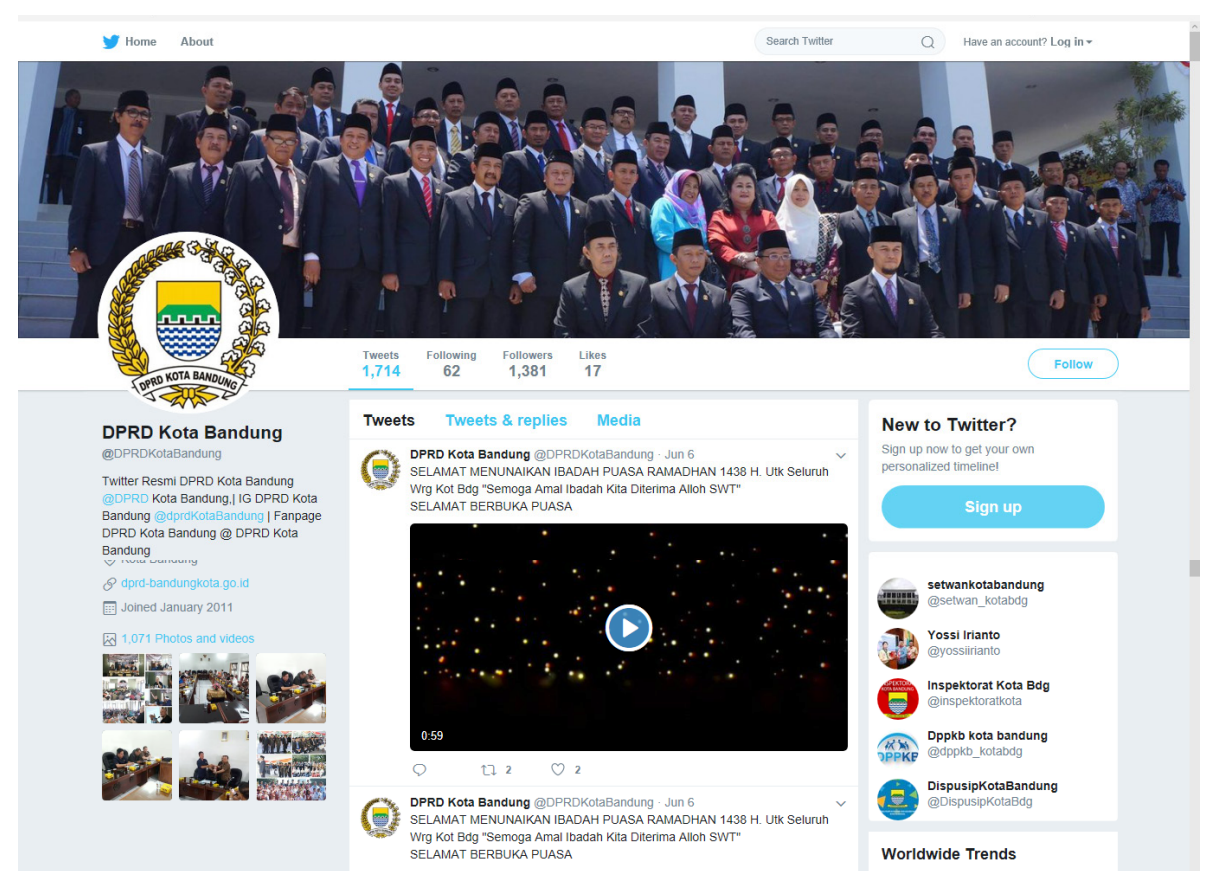

GAMBAR 2. Twitter Lembaga DPRD Kota Bandung (sumber: dok. peneliti) 
trending topic memang sangat sulit.

Masyarakat Kota Bandung sendiri tidak semuanya mengakses informasi mengenai DPRD Kota Bandung melalui akun media sosial instagram dan twitter. Mereka lebih nyaman mendapat informasi dari surat kabar, radio, dan televisi karena aksesnya dianggap lebih mudah dan praktis. Pemilihan media untuk melakukan komunikasi politik dengan masyarakat memang sangat bervariatif, sejauh penelitian yang telah dilakukan, DPRD Kota Bandung sudah semaksimal mungkin melakukan komunikasi politik dengan berbagai jenis media, baik itu media sosial, website, maupun media massa pada umumnya.

\section{SIMPULAN}

Komunikasi politik yang
dilakukan DPRD dalam meningkatkan peran legislatif di Kota Bandung, dilakukan dengan cara berkomunikasi langsung dengan masyarakat yang biasanya di wakili oleh elemen-elemen masyarakat tertentu. Strategi yang digunakan dalam menyampaikan komunikasi politik tersebut dilakukan dengan berbagai cara, mulai dari perencanaan, penyampaian pesan, dan pengelolaan media komunikasi politik. Dalam pengelolaan pesan komunikasi politik, pengelolaan isu-isu politik strategis masih minim dilakukan DPRD Kota Bandung, mereka juga jarang tampil di media massa dan pemberitaan mengenai DPRD Kota Bandung juga sangat minim. Untuk mengatasi hal ini, DPRD Kota Bandung memanfaatkan media sosial untuk melakukan komunikasi yang tidak tersampaikan melalui media massa.

Sementaraitumediayang digunakan dalam penyampaian komunikasi politik
DPRD Kota Bandung dilakukan dengan berbagai cara, baik itu secara langsung, pemanfaatan media massa yang dianggap dapat menjangkau masyarkat yang lebih luas. DPRD Kota Bandung juga memiliki media komunikasi resmi seperti website, instagram, dan twitter. Melalui mediamedia tersebut, DPRD Kota Bandung menyampaikan inforamasi terkait fungsi legislasi mereka sebagai wakil rakyat.

\section{DAFTAR PUSTAKA}

Adiputra, W.M. (2014). Siberaktivisme dalam Komunikasi Politik Pemilihan Umum 2014; Proceeding Seminar Nasional Komunikasi Politik, Malang; Intrans.

Creswell, J. W. (2011). Research Design: Pendekatan Kualitatif, Kuantitatif, dan Mixed, Yogyakarta, Pustaka Pelajar.

Erdianto, K. (2016, September 1). Kompas. com. Retrieved from Kompas. com: http://nasional.kompas.com/ read/2016/09/01/21334701/fungsi. dan.peranan.dprd.belum.maksimal. sudah.minta.naik.gaji

Kriyantono, R. (2007). Teknik Praktis Riset Komunikasi: Disertai Contoh Praktis Riset Media, Public Realation, Advertising, Komunikasi Organisasi, Komunikasi Pemasaran. Jakarta: Kencana.

Moertopo, A. (1974). Strategi Politik Nasional, Jakarta, CSIS.

Nasrullah, R. (2003, April). Komunikasi Politik: Kasus di Jawa Barat, Jurnal Mediator, Vol. 4 (2). 297-300.

Prihatmoko, J.K. (2006, September 28) suaramerdeka.com Retrieved from Suaramerdeka.com: $\quad h t t p: / / w w w$. suaramerdeka.com/harian/0609/28/ opi04.htm

Rodee, C. C, et.all. (2002). Pengantar Ilmu Politik, Jakarta: Raja Grafindo Persada.

Yin, R.K. (2011). Studi Kasus: Desain \& Metode, Jakarta, Rajawali Press. 